\title{
Influence of estuarine processes on spatiotemporal variation in bioavailable selenium
}

\author{
A. Robin Stewart ${ }^{1, *}$, Samuel N. Luoma ${ }^{1,2}$, Kent A. Elrick ${ }^{3}$, James L. Carter ${ }^{1}$, \\ Mick van der Wegen $^{4,5}$ \\ ${ }^{1}$ US Geological Survey, 345 Middlefield Road, Menlo Park, California 94025, USA \\ ${ }^{2}$ John Muir Institute of the Environment, University of California, Davis, 1 Shields Avenue, Davis, California 95616, USA \\ ${ }^{3}$ Georgia State University, 24 Peachtree Center Avenue, Kell Hall, Suite 340, Atlanta, Georgia 30303, USA \\ ${ }^{4}$ UNESCO-International Institute for Infrastructural, Hydraulic and Environmental Engineering (IHE), PO Box 3015 , \\ 2601 DA Delft, The Netherlands \\ ${ }^{5}$ Deltares, PO Box 177, Delft, The Netherlands
}

\begin{abstract}
Dynamic processes (physical, chemical and biological) challenge our ability to quantify and manage the ecological risk of chemical contaminants in estuarine environments. Selenium (Se) bioavailability (defined by bioaccumulation), stable isotopes and molar carbon-tonitrogen ratios in the benthic clam Potamocorbula amurensis, an important food source for predators, were determined monthly for $17 \mathrm{yr}$ in northern San Francisco Bay. Se concentrations in the clams ranged from a low of 2 to a high of $22 \mu \mathrm{g} \mathrm{g}^{-1}$ over space and time. Little of that variability was stochastic, however. Statistical analyses and preliminary hydrodynamic modeling showed that a constant mid-estuarine input of Se, which was dispersed up- and down-estuary by tidal currents, explained the general spatial patterns in accumulated Se among stations. Regression of Se bioavailability against river inflows suggested that processes driven by inflows were the primary driver of seasonal variability. River inflow also appeared to explain interannual variability but within the range of Se enrichment established at each station by source inputs. Evaluation of risks from Se contamination in estuaries requires the consideration of spatial and temporal variability on multiple scales and of the processes that drive that variability.
\end{abstract}

KEY WORDS: Selenium · Bioaccumulation - Exposure $\cdot$ Estuaries $\cdot$ Biomonitoring $\cdot$ Hydrology

\section{INTRODUCTION}

Dietary contaminants such as selenium (Se), mercury and organic chemicals have the potential to threaten fish and birds and to impede ecosystem restoration efforts in rivers, lakes and estuaries worldwide. Selenium contamination remains an ongoing issue for resource managers because it is a by-product of common economic activities including coalfired generation of electricity; oil refining; agriculture; and mining of phosphate, copper and uranium (Chapman et al. 2010). Managing Se waste in nature is complicated because the margin is narrow between Se concentrations that are nutritionally optimal and those that are potentially toxic (Wilber 1980).

*Email: arstewar@usgs.gov
The few studies done to date indicate that understanding the fate and bioavailability of Se in estuaries is especially challenging because of the dynamic nature of source inputs as well as the complexity of Se biogeochemistry, physiological uptake and estuarine hydrodynamics (Cutter 1989, Cutter \& San Diego-McGlone 1990, Cutter \& Cutter 2004, Stewart et al. 2004). A good example of this complexity is found (occurs) in California's San Francisco Bay, where there are multiple sources of Se and where concentrations of Se in food webs vary markedly among species as well as temporally and spatially (Linville et al. 2002, Stewart et al. 2004). It is important to understand the drivers of these complexities in this estuarine ecosystem because future changes

(C) The authors 2013. Open Access under Creative Commons by Attribution Licence. Use, distribution and reproduction are unrestricted. Authors and original publication must be credited. 
in source loading, water management, hydroclimatic conditions and ecosystem restoration could alter Se exposures, potentially exacerbating the problem.

In this paper, a long-term time series (17 yr) of monthly Se concentrations in a biomonitor, the bivalve Potamocorbula amurensis, was used to evaluate temporal and spatial variability in Se in the San Francisco Bay food web. Bioaccumulation of Se in invertebrates has been shown to reflect source inputs and to be related to concentrations of Se in predators, where the most serious impacts are likely to occur. Se in predators can be predicted by prey Se concentrations with a relatively high degree of confidence, if food web structure is generally known (Presser \& Luoma 2010, Stewart et al. 2010). Predators tend to weakly biomagnify Se from their food such that relatively large differences in Se bioaccumulation among invertebrate species (Schlekat et al. 2002, Lee et al. 2006) are often observed in their predators. For example, in San Francisco Bay, Se concentrations in the benthic food web exceed those in the pelagic food web because the resident bottom-dwelling bivalves strongly bioaccumulate Se compared to local pelagic crustacean prey (Stewart et al. 2004). P. amurensis is the predominant bivalve in northern San Francisco Bay. It is a rapidly growing, invasive species that bioaccumulates Se more efficiently than other invertebrates (Linville et al. 2002, Stewart et al. 2004). The predators that are most at risk from Se exposure in the bay are those that feed on $P$. amurensis and other bivalves.

Following the discovery of elevated Se concentrations in clam-eating predators in San Francisco Bay (Ohlendorf et al. 1989, 1991), the US Geological Survey (USGS) and California Water Quality Control Board initiated a monthly monitoring program of Se in Potamocorbula amurensis. Linville et al. (2002) found that Se concentrations in $P$. amurensis differed seasonally from $5 \mu \mathrm{g} \mathrm{g}^{-1}$ dry wt up to $22 \mu \mathrm{g} \mathrm{g} \mathrm{g}^{-1}$ dry wt from 1995 through 1997, but the cause was not clear. Cutter (1989) identified 2 possible sources of enriched Se input to the estuary: effluent from refineries processing oil from the central valley of California and agricultural irrigation runoff from the central valley of California entering the estuary from the San Joaquin River. Mass balance showed that refineries were a large source of Se compared to other inputs, especially during periods of low river inflows (Cutter \& San Diego-McGlone 1990).

But between 1997 and 2011, a number of changes to both Se loading and environmental conditions have occurred that may have driven longer-term changes in Se bioavailability to Potamocorbula amu- rensis. A reduction in Se discharge from the oil refineries in 1998 (Taylor et al. 1992) resulted in a decrease in total Se loads and a change in Se speciation from selenite to selenate and organo-selenium (Cutter \& Cutter 2004). Large year-to-year differences in annual inflow from the rivers as well as increased exports of freshwater from the delta for human consumption also could have affected the concentrations and bioavailability of refinery and San Joaquin River agriculture drainage source contributions. Finally, changes in the quantity or quality of food, including phytoplankton biomass or shifts in phytoplankton community structure (Baines \& Fisher 2001), could potentially influence spatial and temporal variation in Se bioavailability to the clams. Here we show the cumulative effect of a combination of such changes on Se exposures in an estuary by considering hydrology, hydrodynamics, biology of the species involved and ecological processes that could affect Se bioavailability.

We employed monthly Se and stable isotope $(\mathrm{C}, \mathrm{N})$ measurements in Potamocorbula amurensis over a 17 yr period from May 1995 through February 2012 to address the following questions. (1) Has seasonal variability in clam Se concentrations persisted since the earlier studies, and does this variability affect the determination of longer-term trends? (2) Are the causes of seasonal variability different from the causes of longer-term trends? (3) Once seasonal patterns are considered, can changes over the $17 \mathrm{yr}$ be determined and explained? (4) Despite the temporal complexity, do detectable spatial differences in Se concentrations persist through time, and what is their explanation? Although these questions are of particular interest in San Francisco Bay and for the management of Se, their answers and underlying mechanisms are relevant to understanding contaminant exposures in complex estuarine environments across the globe.

\section{MATERIALS AND METHODS}

\section{Sites}

The sites in San Pablo Bay, Carquinez Strait and adjoining Suisun Bay are located near the head of the San Francisco Bay estuary, seaward of the confluence of the Sacramento-San Joaquin rivers (Fig. 1). The area is a major part of the migration corridor and feeding ground for anadromous fish and seasonally is a nursery area for fish that spawn either in freshwater or in the ocean (Kimmerer 2002). This area 


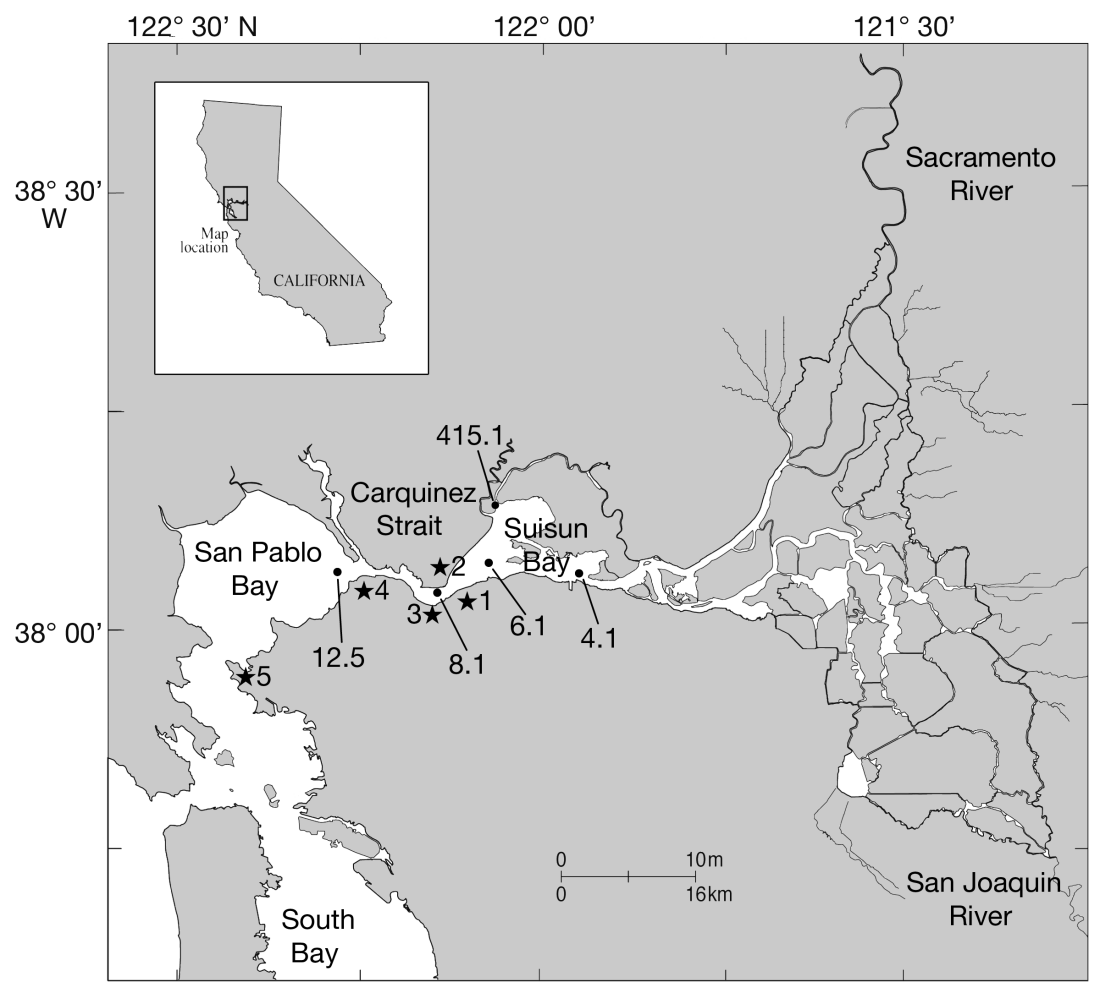

Fig. 1. Sampling locations in northern San Francisco Bay. Circles are site locations. Numbered stars show locations of 5 local oil refineries

\section{Sample preparation and Se and stable isotope analysis}

The estuarine clam Potamocorbula amurensis was collected on a nearmonthly basis from May 1995 through February 2012. The most consistent time series was from Stns 4.1 and 8.1. Approximately 80 individual clams ranging in size from 9 to $18 \mathrm{~mm}$ were collected, placed in water drained from the grab and depurated for $48 \mathrm{~h}$ (Brown \& Luoma 1995). Samples were processed as described in Brown \& Luoma (1995). Briefly, clams of similar length were grouped to form 2 to 3 subsamples per site per date. Each subsample was separately frozen at $-80^{\circ} \mathrm{C}$ until dissected. Soft tissues were removed, pooled by subsample in acid-washed polycarbonate vials (SPEX CertiPrep), weighed to the nearest $0.01 \mathrm{~g}$, refrozen and then freeze-dried (VirTis Freezemobile 12ES). Freeze-dried tissues were weighed and then ground into a coarse powder using a ball mill (SPEX Certi-

further serves migratory birds and year-round species of diving ducks, shorebirds and terns that have been shown to have elevated concentrations of Se (Poulton et al. 2004, Ackerman \& Eagles-Smith 2009). The sites included here extend from the tidal, freshwater delta to San Pablo Bay and are sampled monthly as part of a larger USGS water quality program (http://sfbay.wr.usgs.gov/access/wqdata).

The stations were chosen because they are influenced by different hydrodynamic and estuarine processes (Gross et al. 2010) and may also reflect different sources of Se to the estuary (Fig. 1). Stn 4.1 is nearest the delta and receives inflow from the San Joaquin River, which includes Se-enriched agricultural drainage water (Presser \& Ohlendorf 1987), and the Sacramento River, which is low in Se and provides the bulk of the freshwater inflow into northern San Francisco Bay. Stn 8.1 is located near 4 local oil refineries known to release Se into Carquinez Strait and Suisun Bay (Cutter \& Cutter 2004). Periodic sampling was also conducted at 3 other sites. Stn 415.1, located at the mouth of Montezuma Slough, receives water from both Suisun Bay and the Sacramento River but limited flow from the San Joaquin River. Stn 6.1 lies intermediate along the tidal gradient between Stns 8.1 and 4.1. Stn 12.5 is the farthest down-estuary site in San Pablo Bay and is situated near a single oil refinery.
Prep 5100). A known tissue mass (100 to $200 \mathrm{mg}$ ) was digested in a Teflon beaker using a modification of the procedure described in Elrick \& Horowitz (1985). Specifically, Lefort aqua regia was substituted for nitric acid in the first step of the digestion, and nitric acid was substituted for hydrofluoric acid in the second addition of hydrofluoric-perchloric acids. Samples were then brought up to volume in $0.5 \%$ nitric acid. A $5 \mathrm{ml}$ aliquot was taken and mixed with $5 \mathrm{ml} 12$ $\mathrm{MHCl}$ to reduce the Se and then analyzed by hydride generation atomic absorption spectroscopy (HGAAS). Analysis of Se by HGAAS was done through mid2001, after which Se was quantified by inductively coupled plasma atomic emission spectroscopy. Quality assurance/quality control (QA/QC), which accounted for $20 \%$ of each analytical run, was maintained by the co-digestion and analysis of various standard reference materials from several sources, including the National Institute of Science and Technology, the National Research Council Canada and the International Atomic Energy Agency. A total of $10 \%$ of the clam tissue samples in a run were analyzed in duplicate, and digestion blanks were processed to ensure the purity of the acids and other reagents. Detailed QA/QC results are provided in Table 2 in Kleckner et al. (2010). Se concentrations are expressed on a dry weight basis $\left(\mu \mathrm{g} \mathrm{g}^{-1}\right)$. 
Spatiotemporal variability in food quantity was determined by phytoplankton biomass inferred from near-bed chl a concentrations and suspended particulate material (SPM) and their ratios (chl a:SPM) (for methods see http://sfbay.wr.usgs.gov/access/wqdata). To evaluate variation in the sources and quality of food consumed by Potamocorbula amurensis, stable isotopes and elemental ratios of carbon and nitrogen were measured in soft tissues beginning in July 1999. Stable isotopes have been shown to be effective in identifying contributions of different carbon sources (France 1995) and provide a spatially and temporally integrated measure of trophic relationships in a food web (Peterson \& Fry 1987). In estuaries, variable contributions of source water (e.g. riverine vs. bay water) in time and space can also influence isotopic signatures of carbon and nitrogen entering the base of the food web. For example, algal carbon isotopic signatures are strongly influenced by the $\delta^{13} \mathrm{C}$ values of dissolved inorganic carbon (DIC). The $\delta^{13} \mathrm{C}$ signature of the carbon in DIC is enriched at increasing salinities (Spiker \& Schemel 1979). As phytoplankton populations grow, the phytoplankton cells incorporate a salinity-specific signature of the source DIC (Canuel et al. 1995, Cloern et al. 2002). Shifts in $\delta^{15} \mathrm{~N}$ signatures of nutrients taken up into phytoplankton and propagated up food webs may also occur depending on nitrogen loading and nitrogen recycling (Canuel et al. 1995, Cabana \& Rasmussen 1996, Cloern et al. 2002). Elemental concentrations of carbon and nitrogen (molar ratios) in invertebrates are a qualitative indicator of the nutritional quality of food consumed (Elser et al. 2000) and have been shown to reflect short-term changes in nutrient status of the environment (Smaal \& Vonck 1997). Subsamples of soft tissues of clams were analyzed for carbon and nitrogen content (i.e. molar C:N ratios) and $\delta^{13} \mathrm{C}$ and $\delta^{15} \mathrm{~N}$ ratios at the Stable Isotope Facility, University of California, Davis. Samples were analyzed using a Europa Scientific Hydra 20/20 continuous flow isotope ratio mass spectrometer and Europa ANCA-SL elemental analyzer, which converts organic carbon and nitrogen into $\mathrm{CO}_{2}$ and $\mathrm{N}_{2}$ gas. Results are presented as deviations from standards, expressed as $\delta^{13} \mathrm{C}$ and $\delta^{15} \mathrm{~N}$ :

$$
\delta X=\left[R_{\text {sample }} / R_{\text {standard }}-1\right] \times 10^{3}
$$

where $X$ is ${ }^{13} \mathrm{C}$ or ${ }^{15} \mathrm{~N}$ and $R$ is ${ }^{13} \mathrm{C} /{ }^{12} \mathrm{C}$ or ${ }^{15} \mathrm{~N} /{ }^{14} \mathrm{~N}$. The standard for carbon is Pee Dee Belemnite, and the standard for nitrogen is atmospheric diatomic nitrogen. Instrument precision was $0.1 \%$ for carbon and $0.3 \%$ for nitrogen based on replicate analyses of standard reference materials. Detailed QA/QC results are provided in Kleckner et al. (2010).

\section{Hydrodynamic model simulations}

Preliminary simulations of the physical distribution of Se released from point sources in northern San Francisco Bay were conducted using a 3-dimensional (3D) hydrodynamic model (Delft3D) covering San Pablo Bay and Suisun Bay (see van der Wegen et al. 2011 for model details). Model simulations specified loading of Se from 5 local refineries (Fig. 1) and followed the concentration of Se at Stns 4.1, 8.1 and 12.5 for $60 \mathrm{~d}$ during simulated low (Sacramento inflow = $150 \mathrm{~m}^{3} \mathrm{~s}^{-1}$; San Joaquin River inflow $=50 \mathrm{~m}^{3} \mathrm{~s}^{-1}$ ) and high (Sacramento inflow $=3200 \mathrm{~m}^{3} \mathrm{~s}^{-1}$; San Joaquin River inflow $=800 \mathrm{~m}^{3} \mathrm{~s}^{-1}$ ) inflows. The model simulations assumed constant loading of Se based on values specified in Cutter \& Cutter (2004) and no biological reactions.

\section{Data analysis}

Monthly data and measures of variability for subsamples for clam Se concentrations, clam lengths, soft tissue molar C:N ratios, and $\delta^{15} \mathrm{~N}$ and $\delta^{13} \mathrm{C}$ values are provided in Supplement A (www.int-res.com/ articles/suppl/m492p041_supp.pdf). Correlations between Se concentrations and clam length may bias estimates of mean Se concentrations (Cain \& Luoma 1986, Wang \& Dei 1999b, Lee et al. 2006). To correct for this effect, log Se concentrations were regressed against log clam length for each season using monthly subsamples as replicates $(\mathrm{n}=2-4 \mathrm{mo} \times 2-3$ subsamples) (JMP ${ }^{\circledR 9}$ Fit Model platform, SAS Institute 2010). When there were significant relationships between clam length and Se concentration (see Figs. S2 \& S3 in Supplement B), the relationship was used to calculate Se concentrations at a standard clam length of $13 \mathrm{~mm}$ (grand mean length for entire data set); otherwise, mean monthly Se values were calculated based on the unadjusted mean of 2 to 3 subsamples per month.

Freshwater inflow $\left(\mathrm{m}^{3} \mathrm{~s}^{-1}\right)$ from the delta into San Francisco Bay is estimated by an index of net delta outflow, which corrects total delta outflow for exports to water diversion projects and within-delta diversions (IEP 2006). To determine if freshwater inflows affect Se concentrations (e.g. if higher inflows dilute an internal Se source), it will likely take time for an organism to reflect the change in exposure. A biodynamic model developed for Se bioaccumulation in Potamocorbula amurensis (Lee et al. 2006) was used to determine if a lag or offset in monthly freshwater inflow from Se concentrations in clams was appropri- 
ate to reflect the clams' response to their environment (Supplement C). The results indicated that the best relationships between Se concentrations at Stns 4.1 and 8.1 and freshwater inflow were found using freshwater inflows with a $60 \mathrm{~d}$ offset, which was employed in analyses below.

ANOVA or paired $t$-tests (time as a repeated measure) using JMP ${ }^{\circledR 9}$ (SAS Institute 2010) were used to determine spatial and temporal Se distributions. Means were log-transformed when required to meet assumptions of normality and homogeneity of variances. Post-treatment differences were assessed using Tukey's HSD test and JMP ${ }^{\circledR} 9$ Fit Model (SAS Institute 2010). Relationships between mean Se concentrations and freshwater inflow were evaluated for individual stations across months and for individual seasons across years using JMP ${ }^{\circledR 9}$ Fit Model (SAS Institute 2010).

\section{RESULTS}

\section{Seasonal variability}

Se in Potamocorbula amurensis showed a seasonal pattern within years (Fig. 2, Fig. S1 in Supplement A) (Kleckner et al. 2010). Mean monthly Se concentrations at Stns 4.1 and 8.1 were roughly 2 to $20 \%$ greater than the $17 \mathrm{yr}$ annual mean in September through December $(\mathrm{n}=4 \mathrm{mo})$. These months are defined henceforth as 'fall'. In contrast, Se concentrations were roughly 6 to $34 \%$ less than the $17 \mathrm{yr}$ annual mean in March to June, with the lowest concentrations at both stations in May (Fig. 2). March through June ( $\mathrm{n}=4 \mathrm{mo}$ ) were defined as 'spring'. January and February appeared to be transition months, when concentrations either declined toward the annual mean (Stn 4.1) or remained high (Stn 8.1). July and August fell slightly below (Stn 8.1) or above (Stn 4.1) the 17 yr grand annual mean. Comparison of months grouped into fall and spring seasons across all years showed that clam Se concentrations were greater in the fall relative to the spring at both Stns 4.1 (paired $\left.t_{(9)}=4.82, \mathrm{p}=0.0009\right)$ and $8.1\left(\right.$ paired $t_{(15)}=$ $2.66, \mathrm{p}=0.018)$.

\section{Hydrology}

Freshwater inflow to northern San Francisco Bay (Fig. 2) varies dramatically with season (e.g. Nichols et al. 1986), with lower flows occurring in fall months. Mean Se concentrations for individual months (across all years) decreased linearly with freshwater inflow at Stns $4.1\left(\mathrm{R}^{2}=0.68, \mathrm{n}=12, \mathrm{p}=0.0006\right)$ and $8.1\left(\mathrm{R}^{2}=\right.$ $0.46, \mathrm{n}=12, \mathrm{p}=0.0095$ ) (Fig. $3 \mathrm{~A}$ ). The full range of variability in mean monthly Se concentrations for the corresponding range in mean monthly freshwater inflow was $\sim 3 \mu \mathrm{g} \mathrm{g}^{-1}$ at both stations.

\section{Food sources and quality}

Se is accumulated predominantly via the diet (Luoma et al. 1992); therefore, changes in food source and quality could potentially influence Se uptake by Potamocorbula amurensis. Isotopic signatures of clam tissues are indicative of the sources and quality of foods consumed by the clams, which in the present study appeared to change with freshwater inflows. Stable carbon and nitrogen isotope values were more depleted in the spring than in the fall at Stns 4.1 and 8.1, which is consistent with earlier studies showing depleted isotopic values in clams receiving greater sources of riverine food (Table 1) (Cloern et al. 2002). $\mathrm{Chl}$ a concentrations in Suisun Bay were shown to increase with freshwater inflow from the delta (Jassby 2008); however, increasing monthly chl a concentrations with freshwater inflow in spring months were associated with declining mean monthly Se concentrations at Stns $4.1\left(\mathrm{R}^{2}=0.50, \mathrm{p}=0.006\right)$ and 8.1 $\left(\mathrm{R}^{2}=0.50, \mathrm{p}=0.006\right.$ ) (Fig. 3B). Monthly SPM concentrations were also negatively related to Se concentra-

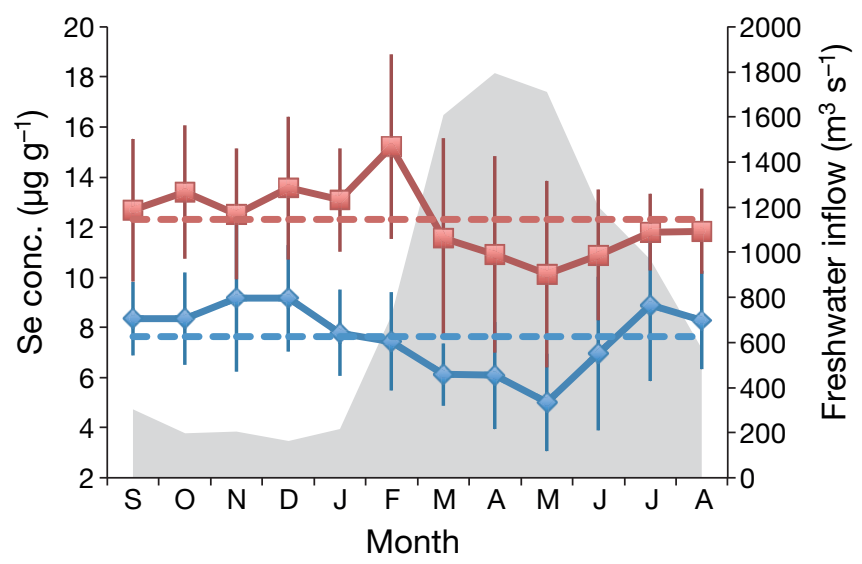

Fig. 2. Monthly Se concentrations in Potamocorbula amurensis at Stns 4.1 and 8.1 from 1995 through 2011. Values are station mean Se concentrations for each month across all years $\pm \mathrm{SD}$, representing among-year variation. Blue diamonds: Stn 4.1; red squares: Stn 8.1. Dashed lines represent the annual mean Se concentrations calculated across 12 mo for each station. Grey shaded area represents mean monthly freshwater inflow lagged by $60 \mathrm{~d}$ (see 'Materials and methods' and Supplement C, available at www.int-res.com/ articles/suppl/m492p041_supp.pdf) 

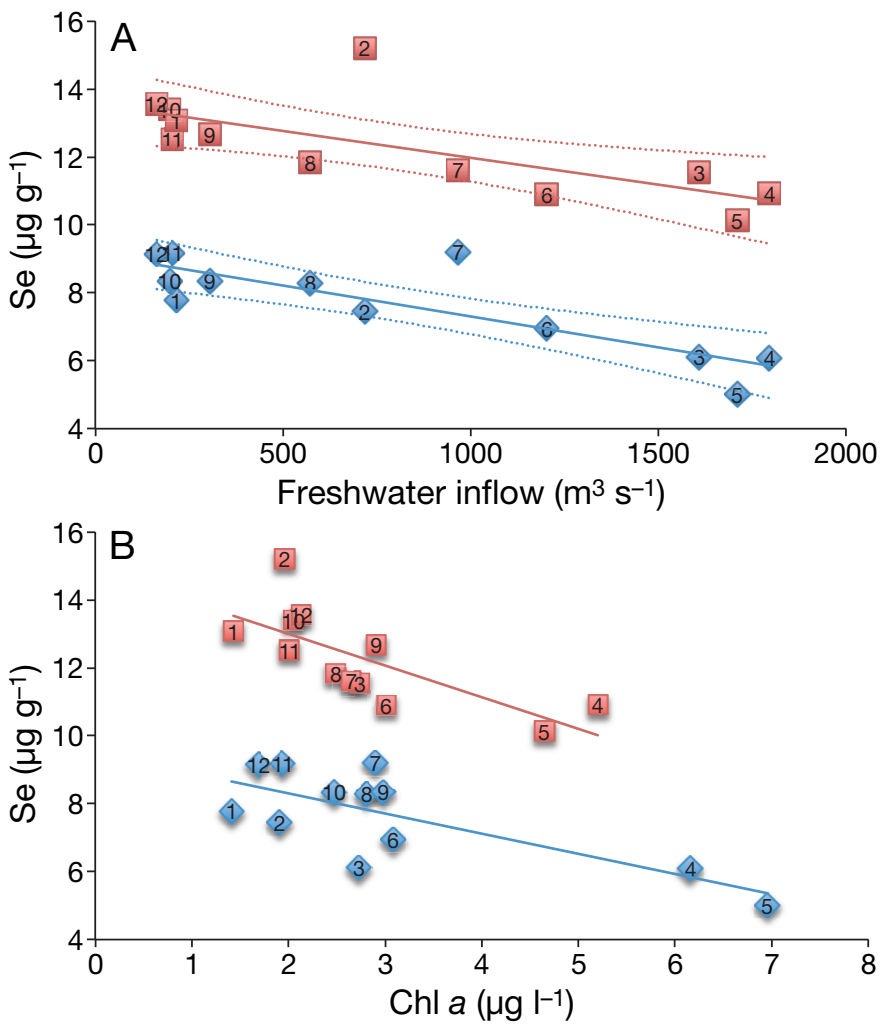

Fig. 3. Relationship between monthly Se concentrations in Potamocorbula amurensis and freshwater inflow and chl a concentrations averaged across all years (1995 through 2011). Values represent individual mean Se concentrations for each month (numbered) of the year for all years. (A) Freshwater inflow. Values lag Se concentrations by $60 \mathrm{~d}$. Regression bounded by $95 \%$ CIs. (B) Chl a concentrations. Values do not lag Se concentrations. Blue diamonds: Stn 4.1; red squares: Stn 8.1. Regressions are significant at $\mathrm{p}=0.05$
Table 1. Stable isotope $\delta^{13} \mathrm{C}$ and $\delta^{15} \mathrm{~N}$ values and molar C:N ratios of clams in fall and spring seasons for years with concurrent data. Values are means \pm SD. Years tested where there were concurrent fall and spring data at each station: Stn 4.1, 2002 to 2011; Stn 8.1, 2000 to 2011

\begin{tabular}{|cccrcccc}
\hline Stn & $\begin{array}{c}\text { Para- } \\
\text { meter }\end{array}$ & Fall & Spring & $t$ & df & $p$ \\
\hline 4.1 & $\delta^{13} \mathrm{C}$ & $-26.94 \pm 0.45$ & $-28.49 \pm 0.95$ & 5.71 & 9 & 0.0003 \\
8.1 & & $-23.78 \pm 0.68$ & $-24.74 \pm 1.35$ & 3.35 & 11 & 0.0065 \\
4.1 & $\delta^{15} \mathrm{~N}$ & $10.50 \pm 1.13$ & $8.50 \pm 1.11$ & 8.63 & 9 & 0.0001 \\
8.1 & & $11.16 \pm 0.67$ & $10.52 \pm 0.95$ & 4.70 & 11 & 0.0007 \\
4.1 & $\mathrm{C}: \mathrm{N}$ & $5.05 \pm 0.17$ & $4.90 \pm 0.45$ & 1.26 & 9 & 0.24 \\
8.1 & & $4.86 \pm 0.16$ & $4.84 \pm 0.17$ & 0.44 & 11 & 0.67 \\
& & & & & & \\
\hline
\end{tabular}

tions at Stn $4.1\left(\mathrm{R}^{2}=0.42, \mathrm{p}=0.013\right.$, data not shown $)$ and showed no relationship at Stn 8.1. Unlike for freshwater inflow, no lag in chl a or SPM values provided the best fit (see 'Discussion'). Despite these apparent changes in the source and quality of food available to the clams in Suisun Bay, clam tissue molar C:N ratios, which are indicative of the nutritional quality of the food consumed by the clams, did not differ between seasons at Stns 4.1 and 8.1 (Table 1).

\section{Interannual variability}

Differences among years were evaluated using data constrained to the fall and the spring to reduce the complexities of seasonality. Se concentrations in the clams during fall declined rapidly at all stations after refinery treatment began in 1998 (Fig. 4A). With
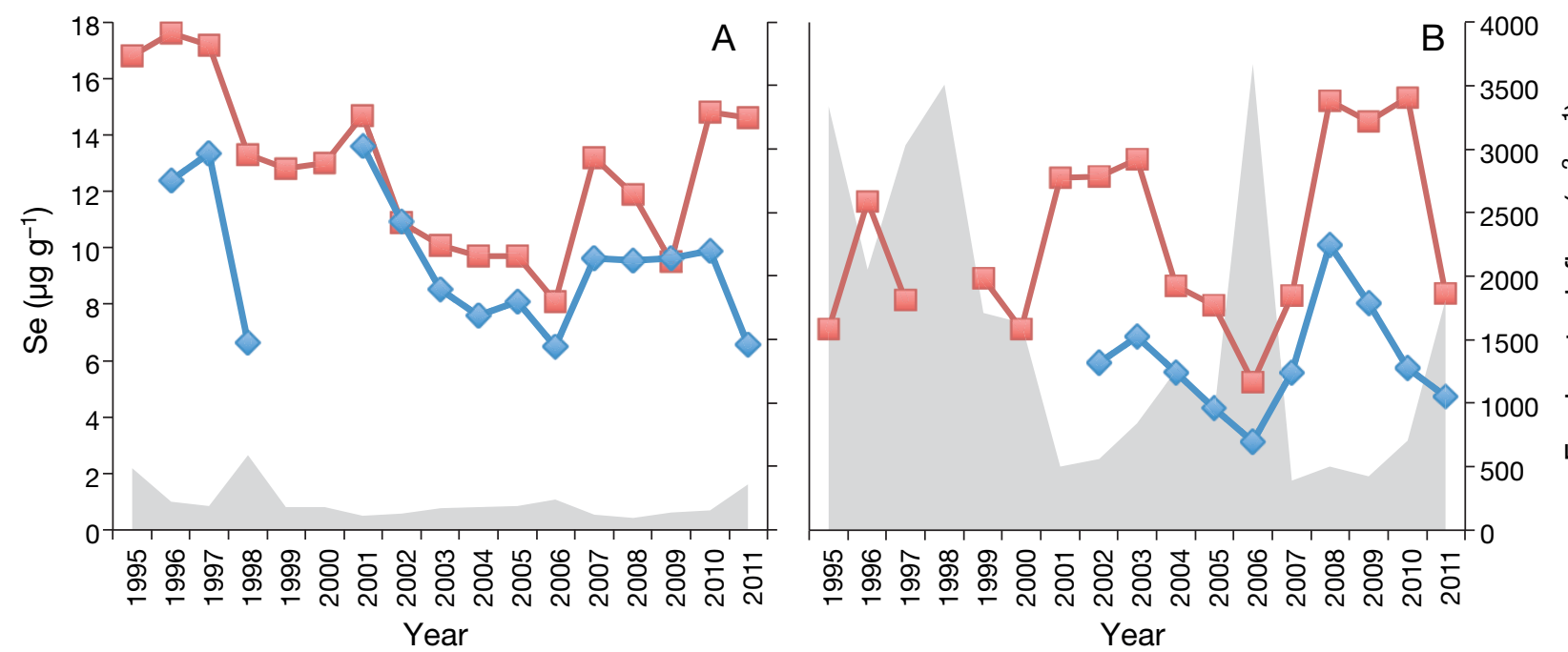

Fig. 4. Se concentrations in Potamocorbula amurensis at Stns 4.1 and 8.1 in (A) fall and (B) spring 1995 through 2011. Se values are means for fall (adjusted for clam length) and spring (no length adjustment) months. Blue diamonds: Stn 4.1; red squares: Stn 8.1. Grey shaded area represents means of freshwater inflow for fall (July to October, $\mathrm{n}=4$ ) and spring (January to April, $\mathrm{n}=4$ ) for each year (www.water.ca.gov/dayflow/) 
Table 2. Clam length and Se concentrations in fall pre-treatment (1995 to 1997) and post-treatment (1998 to 2011$)$ of refinery effluents. Values are means \pm SD

\begin{tabular}{|c|c|c|c|c|c|c|c|c|c|c|}
\hline \multirow[t]{2}{*}{ Stn } & \multicolumn{2}{|c|}{ - Length $(\mathrm{mm})-$} & \multirow[t]{2}{*}{$t$} & \multirow[t]{2}{*}{ df } & \multirow[t]{2}{*}{$\mathrm{p}$} & \multicolumn{2}{|c|}{${ }_{-} \operatorname{Se}\left(\mu g g^{-1}\right) \amalg$} & \multirow[t]{2}{*}{$t$} & \multirow[t]{2}{*}{ df } & \multirow[t]{2}{*}{$\mathrm{p}$} \\
\hline & Pre-treatment & Post-treatment & & & & Pre-treatment & Post-treatment & & & \\
\hline \multirow[t]{2}{*}{4.1} & $20.05 \pm 0.65$ & $15.21 \pm 3.06$ & 2.13 & 12 & 0.054 & $11.3 \pm 0.4$ & $8.7 \pm 2.4$ & 1.51 & 12 & 0.156 \\
\hline & & & & & & $12.9 \pm 0.7^{\mathrm{a}}$ & $8.9 \pm 2.1^{\mathrm{a}}$ & 2.35 & 12 & 0.037 \\
\hline \multirow[t]{2}{*}{8.1} & $15.38 \pm 1.55$ & $12.50 \pm 1.21$ & 3.32 & 15 & 0.005 & $16.0 \pm 0.6$ & $12.3 \pm 2.4$ & 2.30 & 15 & 0.036 \\
\hline & & & & & & $17.2 \pm 0.4^{\mathrm{a}}$ & $11.9 \pm 2.2^{\mathrm{a}}$ & 8.40 & 15 & 0.0001 \\
\hline
\end{tabular}

the exception of 2001, Se continued to decline at Stns 4.1 and 8.1 until 2007. This trend reversed direction in 2007, with higher concentrations through 2011. Data available for other stations $(6.1,12.5$ and 415.1) were generally consistent with Stns 4.1 and 8.1 (Fig. S1 in Supplement $A_{i}$ Kleckner et al. 2010). Most importantly, fall Se concentrations were $~ 30 \%$ higher in the pre-treatment years (1995 to 1997) than in the post-treatment years (1999 to 2011) at both Stns 4.1 and 8.1 (Table 2).

Interannual patterns in Se concentrations in the spring were complex at Stns 4.1 and 8.1. There were no statistically significant differences in spring Se concentrations between pre- and post-treatment years at Stn 8.1, nor was the decade-long decline through 2006 evident as was observed in fall (Fig. 4B). Se concentrations at Stn 8.1 were elevated in 1996 and 2001-2003 and were perhaps highest in 2008-2010 (Fig. 4B). A similar pattern was observed for Stn 4.1, with elevated concentrations in 20022004 compared to 2005-2007 and the highest values in 2008 and 2009.

\section{Hydrology}

Freshwater inflow to northern San Francisco Bay varied among years over the $17 \mathrm{yr}$ period of study. Inflows followed rainfall, which ranged from wet to critically dry water years (Fig. 4). During the fall, there was no relationship between Se concentrations in clams and freshwater inflow at Stn 8.1; however, Se was negatively related to freshwater inflow at Stn 4.1 (Fig. 5A). During the spring, Se was negatively related to freshwater inflow at both Stns 8.1 and 4.1. The relationships between freshwater inflow and fall and spring Se concentrations (Fig. 5A,B) were sufficiently similar at Stn 4.1 that a single negative relationship could be calculated using log-transformed freshwater inflow values: Se concentration $=-2.1 \times \log$ freshwater inflow $+20\left(R^{2}=0.66, p<0.0001\right)$ (Fig. $\left.5 C\right)$. This pro- vides an estimated maximum effect of $\sim 7.1 \mu \mathrm{g} \mathrm{g}^{-1}$ for Se concentrations in clams at Stn 4.1 across the full range of inflow variability.

At Stn 8.1, the relationships between interannual Se concentrations and freshwater inflow were more complex. Se concentrations in the fall ranged from 8 to $16 \mu \mathrm{g} \mathrm{g}^{-1}$ over a very small range of inflow rates (most $<400 \mathrm{~m}^{3} \mathrm{~s}^{-1}$ ) (Fig. 5A). In spring, the entire relationship was shifted to the right (Fig. 5B). Spring discharge rates of $<1000 \mathrm{~m}^{3} \mathrm{~s}^{-1}$ were accompanied by mean Se concentrations nearly as high as concentrations in fall. When average spring inflows exceeded $1000 \mathrm{~m}^{3} \mathrm{~s}^{-1}$, Se concentrations in clams were driven downward accordingly (Fig. 5B).

\section{Source inputs}

Se concentrations for combined fall and spring seasons at Stn 8.1 were $23 \%$ higher in pre-treatment years than in post-treatment years (ANCOVA; $\left.F_{(2,30)}=9.27, \mathrm{p}=0.0007\right)$ and displayed a negative relationship with freshwater inflow: Se concentration $=-2.9 \times \log$ freshwater inflow $+32\left(\mathrm{R}^{2}=0.88\right.$, $p=0.0038$ ). Unfortunately, there were insufficient data to test the relationship at Stn 4.1 during pretreatment years. During post-treatment years, the relationship between Se and flow was shifted downward at Stn 8.1 (Se concentration $=-1.26 \times \log$ freshwater inflow $+18.76\left(R^{2}=0.16, p=0.021\right)$ (Fig. 5C). Thus, the effect of Se inputs was to set the level (intercept) around which hydrology drove fluctuations in concentrations year to year. That level declined $23 \%$ after refineries improved waste treatment. The full range in freshwater inflow among years resulted in fall and spring mean Se concentrations in clams (post-treatment) that ranged from 7 to $15 \mu \mathrm{g} \mathrm{g}^{-1}$, with highest concentrations during the years of lowest inflows. Pre-treatment freshwater inflow appeared to drive the range of Se concentrations from 8.5 to $18 \mu \mathrm{g} \mathrm{g}^{-1}$. 

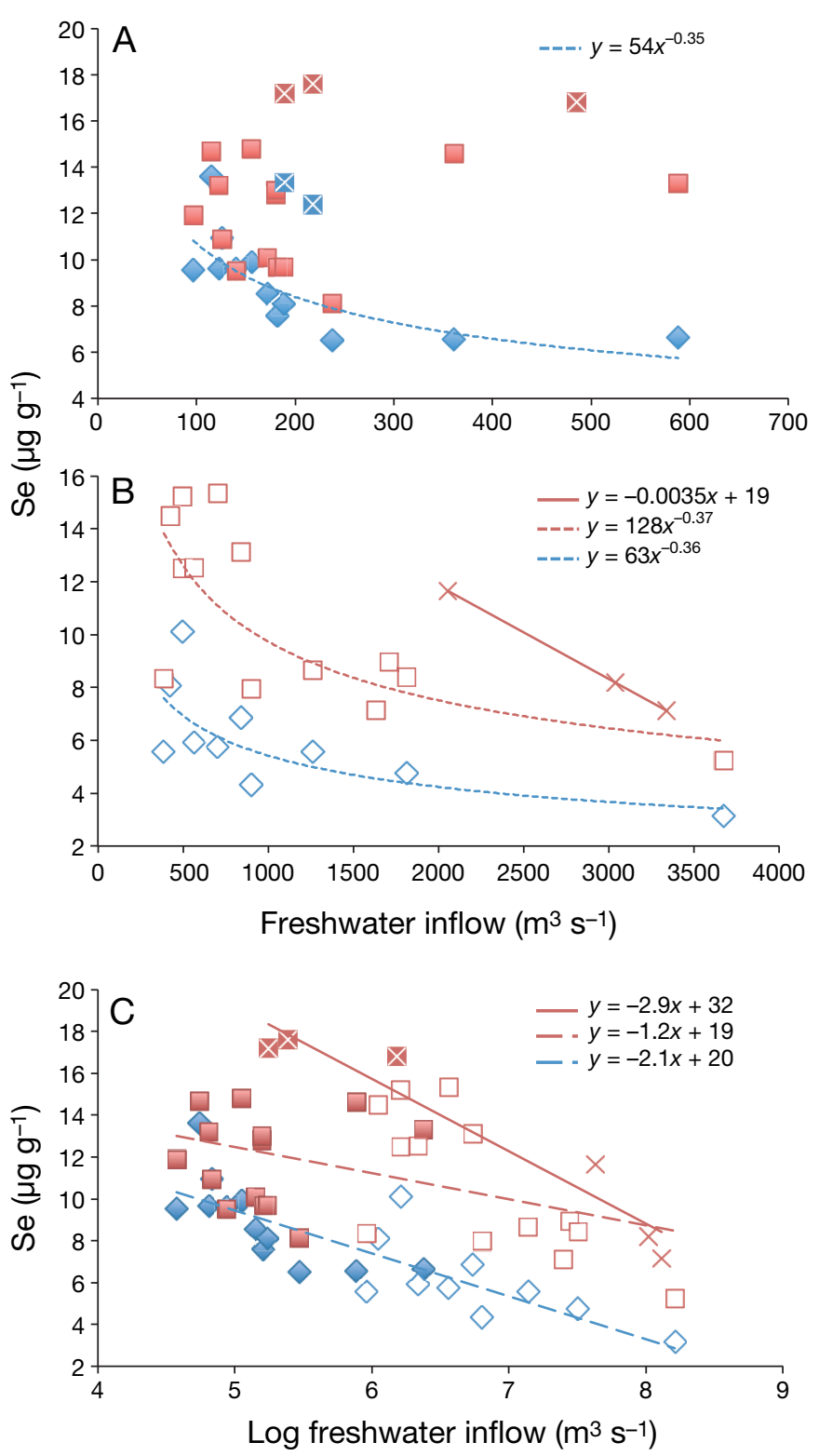

Fig. 5. Relationship between fall and spring Se concentrations in Potamocorbula amurensis at Stns 4.1 and 8.1 and freshwater inflow for 1995 through 2011. Se values are seasonal means for fall (adjusted for clam length) and spring (no length adjustment) months. Freshwater inflow values are annual means of flow for July through October (fall) and January through April (spring) of each year. Blue diamonds: Stn 4.1; red squares: Stn 8.1; closed symbols: fall; open symbols: spring; cross symbols: pre-treatment of refineries. (A) Fall. (B) Spring. (C) Fall and spring. Significant best-fit regression relationships $(p<0.05)$ are shown for Stn 4.1 fall and spring (short dashed blue line) and Stn 8.1 spring (short dashed red line) and for Stn 8.1 pre-treatment years in the spring (solid red line). Significant best-fit regression relationships between Se concentrations and log-transformed freshwater inflow values (fall and spring combined) are shown for Stn 8.1 pre-treatment (solid red line) and posttreatment years (long dashed red line) and for Stn 4.1 posttreatment years (long dashed blue line)
Clam length

The distributions of clam lengths in the fall differed before and after treatment of refinery effluents. The years before refineries improved waste treatment (1995 to 1997) tended to have larger clams than posttreatment years at Stns 4.1 and 8.1 (Table 2). Adjusting fall Se concentrations to a standard-sized clam of $13 \mathrm{~mm}$ further resolved differences in fall Se concentrations pre- and post-treatment at Stn 8.1 that were present prior to size adjustment and identified a difference at Stn 4.1 not evident in unadjusted data (Table 2).

Food sources and quality

Stable isotope signatures of nitrogen and to a lesser degree carbon varied among years in both the spring and fall at Stns 4.1 and 8.1, indicating that food sources (riverine vs. bay) for the clams may have also varied among years (Figs. S5 \& S6 in Supplement D). Interannual variation in $\delta^{15} \mathrm{~N}$ values of the clams at both stations was negatively related to freshwater inflow and positively related to X2 (Fig. 6A, X2 values lag $60 \mathrm{~d}$ ). X2 reflects the relative position along the axis of the estuary, where bottom water has a salinity of 2 (Jassby et al. 1995). In general, as X2 moves upestuary, both Stns 8.1 and 4.1 receive proportionally less freshwater inflow and have longer water residence times; therefore, phytoplankton communities increasingly reflect local estuarine conditions as indicated by enriched $\delta^{15} \mathrm{~N}$ values. Increasing Se concentrations were positively related to increasing values of $\delta^{15} \mathrm{~N}$ at $\operatorname{Stn} 4.1\left(\mathrm{n}=21, \mathrm{R}^{2}=0.71, \mathrm{p}<0.0001\right)$ as well as at $\operatorname{Stn} 8.1\left(\mathrm{n}=25, \mathrm{R}^{2}=0.41, \mathrm{p}=0.0003\right)$ (Fig. 6B). The relationship between $\delta^{15} \mathrm{~N}$ and Se concentrations in the clams was similar at both stations for $\delta^{15} \mathrm{~N}$ values up to $10 \%$, but at higher $\delta^{15} \mathrm{~N}$ values, the relationship was shifted further upward at Stn 8.1.

Despite the possibility of a changing source of food, molar C:N ratios (an indicator of the quality of the food) were very consistent and did not appear to explain interannual variation in Se concentrations (Fig. S1C in Supplement D). Indeed, the quantity/quality of clam food in the fall or spring, as defined by chl $a_{1}$ SPM and $\mathrm{chl} a: S P M$, was not related to interannual variability in Se concentrations in clams (Fig. S7 in Supplement D).

\section{Spatial distributions}

Distributional patterns in Se concentrations were persistent through the $17 \mathrm{yr}$ of the study (Table 3). 

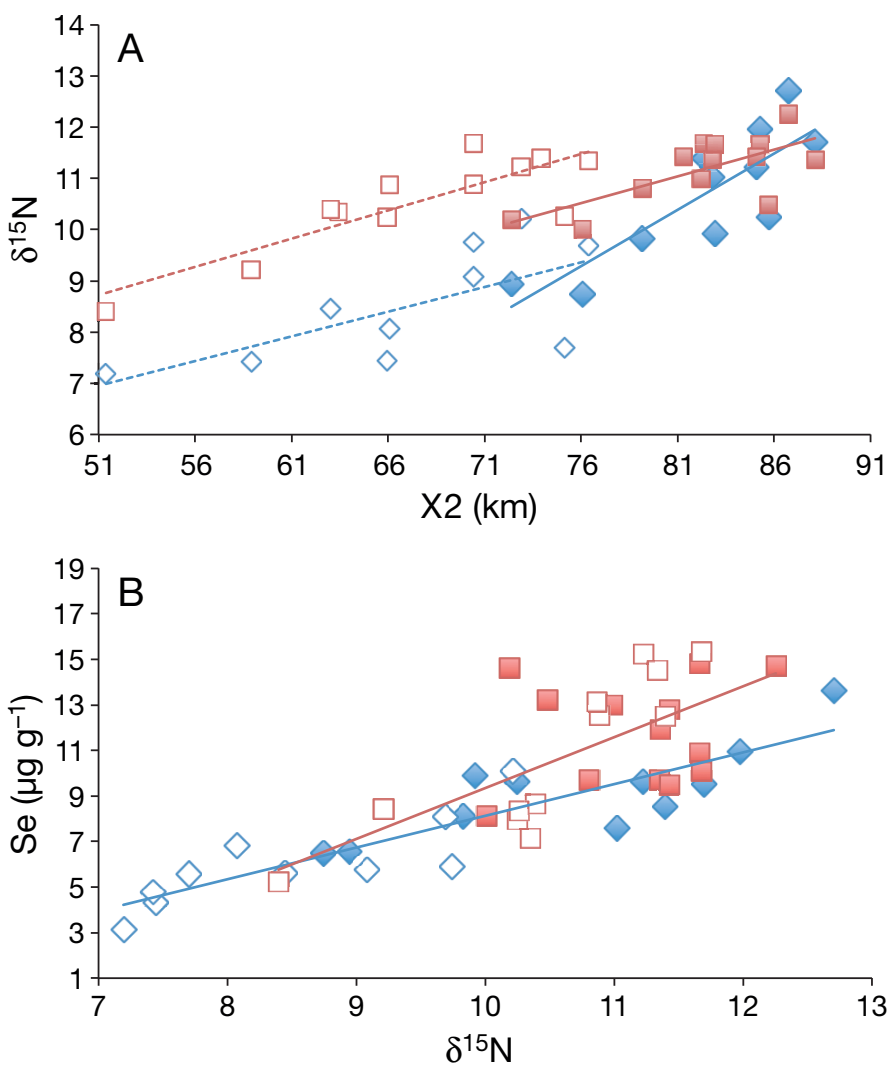

Fig. 6. Relationship between fall and spring $\delta^{15} \mathrm{~N}$ in Potamocorbula amurensis at Stns 4.1 and 8.1 and X2 or Se concentrations in clams from 1999 through 2011. Stable nitrogen values are seasonal means for fall and spring months. (A) X2 represents the position (in $\mathrm{km}$ from Golden Gate Bridge) of a salinity of 2 in bottom water. X2 values are annual means of X2 for fall (July through October, $\mathrm{n}=4$ ) and spring (January through April, $\mathrm{n}=4$ ) of each year. Significant regression relationships are shown separately for each station and season. (B) Se concentrations and $\delta^{15} \mathrm{~N}$ values are seasonal means for fall and spring months. Blue diamonds: Stn 4.1; red squares: Stn 8.1; closed symbols: fall; open symbols: spring. Significant regression relationships are shown separately for each station

Table 3. Differences in Se concentrations between Stn 8.1 and other stations in the fall and spring for years where there were concurrent data at each station. Values are means for the years tested at each station. Values for Stns $4.1,8.1$ and 415.1 in the fall were calculated using Se concentrations adjusted to a clam length of $13 \mathrm{~mm}$ based on relationships between Se concentrations and clam length in the fall for each station

\begin{tabular}{|cccccccc|}
\hline Years tested & Stn & $\begin{array}{c}\text { Se } \\
\left(\mu \mathrm{g} \mathrm{g}^{-1}\right)\end{array}$ & $\begin{array}{c}\text { Stn 8.1 Se } \\
\left(\mu \mathrm{g} \mathrm{g}^{-1}\right)\end{array}$ & $t$ & $\mathrm{df}$ & $\mathrm{p}$ \\
\hline $1996-2011$ & 4.1 & 7.3 & 10.9 & 6.39 & 23 & 0.0001 \\
$1995-1999$ & 6.1 & 12.1 & 13.1 & 1.73 & 5 & 0.14 \\
$1995-1999$ & 12.5 & 10.5 & 13.7 & 3.39 & 5 & 0.020 \\
$1999-2003$ & 415.1 & 8.6 & 11.6 & 6.81 & 6 & 0.0005 \\
\hline
\end{tabular}

Clams from mid-estuarine Stn 8.1, near Carquinez Strait, had the highest Se concentrations in both the fall and spring compared to up-estuary Stn 4.1 (33\% lower than Stn 8.1, mean difference $=3.6 \mu \mathrm{g} \mathrm{g}^{-1}$ ) and down-estuary Stn 12.5 (23\% lower than 8.1, mean difference $=3.2{\left.\mu \mathrm{g} \mathrm{g}^{-1}\right)}$ as well as Stn $415.1(26 \%$ lower than Stn 8.1, mean difference $=3.2 \mu \mathrm{g} \mathrm{g}^{-1}$ ), located at the northern entry point to Suisun Bay. Se concentrations tended to be greater at Stn 8.1 but did not differ from Stn 6.1 (the closest station to Stn 8.1 in Suisun Bay) for the years tested (mean difference $=1 \mu \mathrm{g} \mathrm{g}^{-1}$ ).

\section{Source inputs}

The locations of the sampling stations were chosen relative to potential sources of Se inputs. Stn 8.1 is located near 4 local oil refineries known to continuously release Se into Carquinez Strait and Suisun Bay (Cutter \& Cutter 2004). All refineries together discharged on average $789 \mathrm{~kg} \mathrm{yr}^{-1}$ of Se to the estuary in this region from 2005 to 2008 (based on publicly available effluent records), after the improvements in Se removal. Stn 4.1, nearest the delta, is the closest station to inflows from the San Joaquin River, which could bring waters enriched in Se from agricultural drainage into the bay when it is not being recycled back to the central valley (Presser \& Ohlendorf 1987). The higher concentrations of Se in clams from Stn 8.1 compared to Stn 4.1 over the entire $17 \mathrm{yr}$ of study, in both fall and spring, suggest that a process that is continuous in time drives the gradient. This would not be consistent with Se inputs from the San Joaquin River. Thus, local inputs within the region where the refineries are located would be the simplest explanation for the spatial pattern if it were feasible that tidal advection, diffusion and other dispersive processes around Stn 8.1 could transport Se to the other sites up- and down-estuary.

\section{Hydrology and hydrodynamics}

Strong tidal currents in the bay will mix Se throughout the tidal range both landward and seaward from a source of input. Although concentrations of Se in clams differed among stations, they co-varied among stations across months and years (Fig. S1 in Supplement A): Stn 8.1 vs. Stn $4.1, \mathrm{n}=94$, pairwise $\mathrm{r}=0.45$, $\mathrm{p}<0.0001$; Stn 8.1 vs. Stn 6.1, $\mathrm{n}=11$, pairwise $\mathrm{r}=0.94$; $\mathrm{p}<0.0001$ (monthly concentrations were not adjusted for differences in clam length). The relationships suggested that at least some of the temporal variabil- 
ity was driven by the same processes at all stations, as might be expected if a driver common throughout the estuary (e.g. hydrology, hydrodynamics) affected an exposure common to the estuary (e.g. one dominant source of Se).

Continuous inputs of Se to a site may allow a detectable spatial gradient to develop despite the complexities of estuarine hydrodynamics (e.g. Cutter \& San Diego-McGlone 1990). Although the distance between Stn 8.1 at Carquinez Strait and Stn 4.1 is greater than a single tidal excursion (D. Schoellhamer pers. comm.), multiple tidal cycles could theoretically disperse the Se from a source at Stn 8.1 to

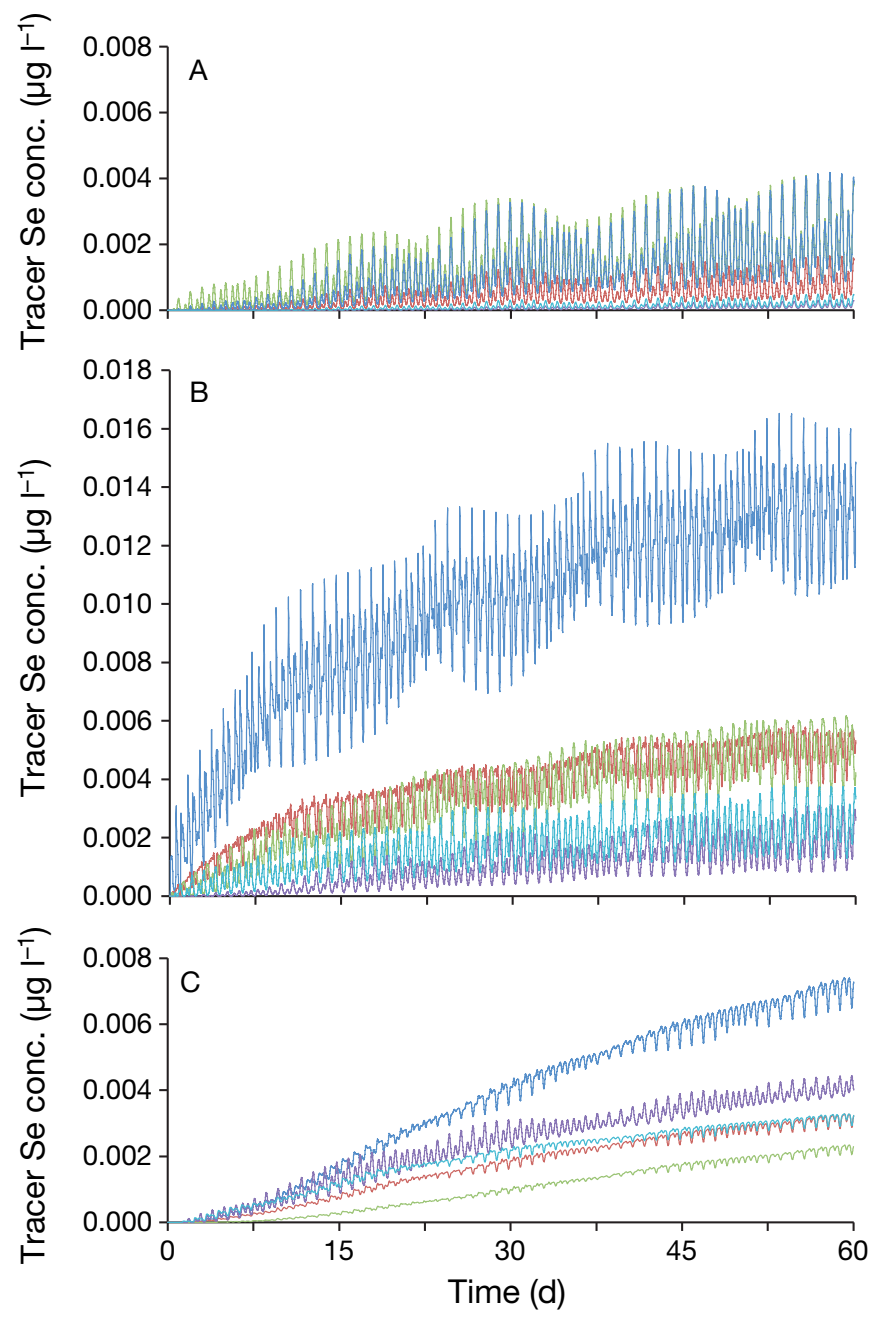

Fig. 7. Relative Se tracer concentrations $\left(\mu \mathrm{g} \mathrm{l}^{-1}\right)$ in mid-water near Stns 4.1, 8.1 and 12.5 following a 2 mo simulation (Delft3D) of Se transport in northern San Francisco Bay under low-flow conditions (Sacramento River $=150 \mathrm{~m}^{3} \mathrm{~s}^{-1}$, San Joaquin River $=50 \mathrm{~m}^{3} \mathrm{~s}^{-1}$ ). Simulation specifies conservative transport of Se tracers and Se loading from 5 local area refineries. (A) Stn 4.1. (B) Stn 8.1. (C) Stn 12.5. Green line: Refinery $1\left(171 \mathrm{~g} \mathrm{~d}^{-1}\right)$; red line: Refinery $2\left(197 \mathrm{~g} \mathrm{~d}^{-1}\right)$; blue line: Refinery $3\left(455 \mathrm{~g} \mathrm{~d}^{-1}\right)$; light blue line: Refinery 4 $\left(180 \mathrm{~g} \mathrm{~d}^{-1}\right)$; purple line: Refinery $5\left(509 \mathrm{~g} \mathrm{~d}^{-1}\right)$ this up-estuary location, as is observed for other constituents in the estuary including salt and suspended sediment (Monismith et al. 2002, Ganju \& Schoellhamer 2006). To directly test if this would be possible for Se inputs to Stn 8.1, preliminary simulations using a 3D hydrodynamic model (Delft3D) covering San Pablo Bay and Suisun Bay were conducted that specified constant loading of Se from the 5 local refineries (Fig. 1) over a period of $60 \mathrm{~d}$. During low river inflows, such as those typical of the fall, the model predicts an increase in tracer Se concentrations through time at Stns 12.5, 8.1 and 4.1 from the refineries (Figs. $7 \&$ 8). After $60 \mathrm{~d}$ of the simulation, summed tracer Se concentrations at Stn 8.1 were approximately $67 \%$ higher than those at Stn 4.1 and $34 \%$ higher than those at Stn 12.5 (Fig. 8).

The model indicated that during high flow (Sacramento River $=3200 \mathrm{~m}^{3} \mathrm{~s}^{-1}$, San Joaquin River flow = $800 \mathrm{~m}^{3} \mathrm{~s}^{-1}$ ), considerably less tracer Se would be accumulated at Stns 8.1 or 12.5 , and no refinery tracer Se is detected up-estuary at Stn 4.1 (data not shown). A 60 d simulation cannot assess the ultimate accumulation of Se concentrations in this system, but it does suggest that it is feasible that the relative distribution of Se among stations, as observed in the clams, could be explained by dispersion from a single source of input near Stn 8.1.

\section{Food source and quality}

The complexities of estuarine ecological processes offer alternatives to the source load-driven explanation of the spatial gradient suggested above. 3D

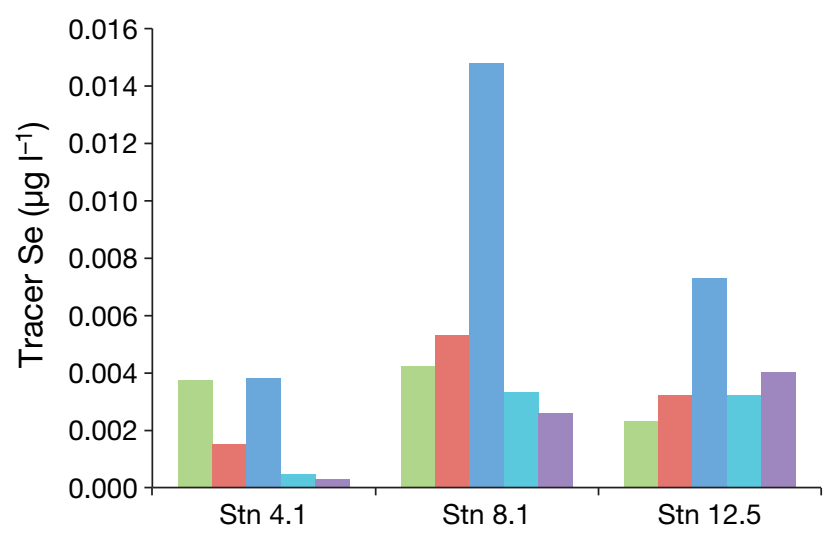

Fig. 8. Total Se tracer concentrations $\left(\mu \mathrm{g} \mathrm{l}^{-1}\right)$ for all refinery sources in mid-water near Stns 4.1, 8.1 and 12.5 after 2 mo simulation (Delft3D) of Se transport in northern San Francisco Bay under low-flow conditions and conservative transport of Se tracers and Se loading from 5 local area refineries. Green bar: Refinery 1; red bar: Refinery 2; blue bar: Refinery 3; light blue bar: Refinery 4; purple bar: Refinery 5 
hydrodynamics may concentrate a constituent, such as nutrients, in a given area (e.g. if this is a 'null zone'). Landward to seaward increases in residence time are also possible that could facilitate a landward to seaward decrease in SPM and increase in phytoplankton (Jassby 2008), which could be an important source of Se for the clams (Chen et al. 2012).

To determine if there was a consistent spatial pattern in isotope signatures that might be indicative of spatial differences in the source and quality of food consumed by clams, monthly measurements of $\delta^{13} \mathrm{C}$ and $\delta^{15} \mathrm{~N}$, collected concurrently at most stations in a single year during low inflows, were compared among stations (September through December 1999; Fig. 9). Since no samples were collected at Stn 4.1 for this year, we selected isotope data for Stn 4.1 for July through December in 2004, which was a year when Stn 8.1 isotope data were statistically similar to 1999. For this time period, $\delta^{13} \mathrm{C}$ values were distinct among stations, becoming progressively more enriched moving down-estuary from Stn $4.1\left(\delta^{13} \mathrm{C}=-26.55 \pm\right.$ $0.39 \mathrm{SD})$ to $\operatorname{Stn} 12.5\left(\delta^{13} \mathrm{C}=-22.68 \pm 0.08 \mathrm{SD}\right)$ as the proportion of carbon derived from freshwater sources declined (Fig. 9) (Spiker \& Schemel 1979, Canuel et al. 1995). Nitrogen isotope values were less distinct but showed a slight enrichment down-estuary from $\operatorname{Stn} 4.1\left(\delta^{15} \mathrm{~N}=11.02 \pm 0.41 \mathrm{SD}\right)$ to $\mathrm{Stn} 8.1$ $\left(\delta^{15} \mathrm{~N}=11.43 \pm 0.35 \mathrm{SD}\right)$ and then depletion at Stn 12.5 $\left(\delta^{15} \mathrm{~N}=10.47 \pm 0.34 \mathrm{SD}\right)$.

There were some spatial differences in food quantity (i.e. chl a or SPM), but differences did not follow a down-estuary pattern as for $\delta^{13} \mathrm{C}$ or a mid-estuary peak (fall and spring) as did Se concentrations at Stn 8.1 (Fig. S7 in Supplement D). Fall chl a concentra-

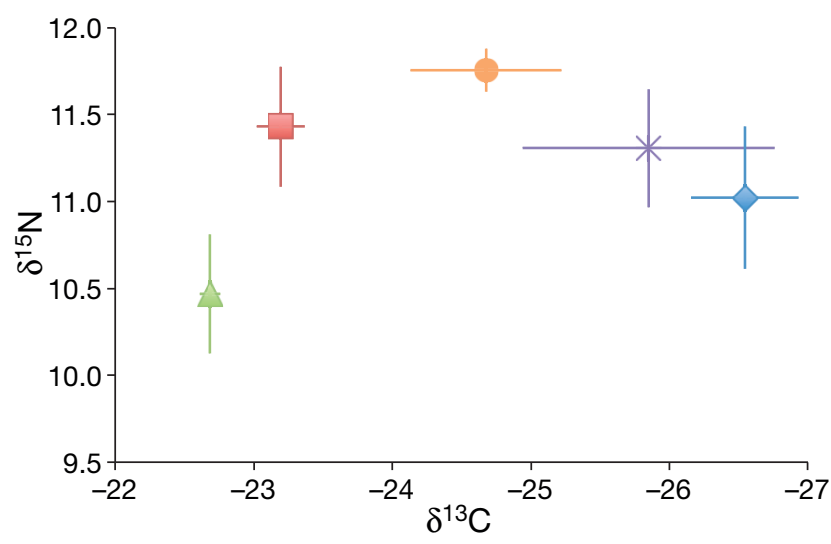

Fig. 9. Stable carbon $\left(\delta^{13} \mathrm{C}\right)$ and nitrogen $\left(\delta^{15} \mathrm{~N}\right)$ values of Potamocorbula amurensis in fall 1999 at Stns 6.1, 8.1, 12.5 and 415.1 and in 2004 at $\mathrm{Stn} 4.1$. Values are means $\pm \mathrm{SD}, \mathrm{n}=$ 3 mo. Blue diamonds: Stn 4.1; orange circles: Stn 6.1; red squares: Stn 8.1; green triangles: Stn 12.5; purple crosses: Stn 415.1 tions were similar between Stns 4.1 and 8.1 but higher at Stn 12.5 (paired $t$-tests, p < 0.01). There were no differences in chl a among stations in the spring. SPM concentrations in the fall decreased, and chl a:SPM increased down-estuary from Stn 4.1 to Stn 12.5 (paired $t$-tests, $\mathrm{p}<0.01$ ), but in the spring, the highest SPM and lowest chl a:SPM values were found at Stn 8.1 (paired $t$-tests, $\mathrm{p}<0.01$ ). Despite apparent spatial differences in food sources, the nutritional quality of food consumed by the clams, as indicated by molar $\mathrm{C}: \mathrm{N}$ ratios (for the time period described above), did not differ among stations (ANOVA, $F_{4,10}=2.32, \mathrm{p}=0.13$ ).

\section{DISCUSSION}

\section{Patterns of estuarine variability in Se bioavailability}

One of the challenges in understanding the fate and effects of Se in estuaries is that small changes in Se concentrations in solution or on particulate material can result in large changes in Se bioaccumulation (Johns et al. 1988, Stewart et al. 2004, 2010). Much has been learned about Se dynamics, biogeochemistry, and bioavailability in San Francisco Bay (e.g. Cutter 1989, Cutter \& San Diego-McGlone 1990, Cutter \& Cutter 2004). The high frequency of sampling, the long-term continuous nature of the present study and the elevated Se concentrations (as compared to dissolved and suspended sediment concentrations) in the biomonitor Potamocorbula amurensis from Suisun and San Pablo bays allowed some new insights, however. Most important is the very high variability in time and space of bioavailable Se concentrations. Very little of this variability was intractable once inputs and estuarine processes were considered. Patterns in Se were a function of location, inputs, hydrology, hydrodynamics and biology at both seasonal and annual scales. This type of complexity is probably typical of many estuaries where the ecosystem is enriched with Se or other trace metals of concern.

The persistent spatial pattern of Se concentrations in Potamocorbula amurensis, with a mid-estuarine peak near Carquinez Strait, is broadly similar to spatial distributions of Se in solution during low flows from the 1980s and 1990s (Cutter 1989, Cutter \& Cutter 2004), suspended particulate matter as observed in January 2000 through fall 2002 (Doblin et al. 2006) and Se concentrations in $P$. amurensis observed in spatially intense samplings (Linville et al. 2002). The 
persistence of a maximum in Se at Stn 8.1 regardless of seasonal and annual variations in hydrology, estuarine hydrodynamics and biological factors strongly indicates the importance of source inputs near Carquinez Strait. Preliminary 3D hydrodynamic modeling indicates that estuarine hydrodynamics could drive the entire spatial distribution by dispersing $\mathrm{Se}$ up- and down-estuary from the predominant source, although the model could not fully explain the degree of difference among stations. Patterns in the spatial distribution of chl a and variability in the nature of the food consumed by the bivalves (identified by their stable isotope signatures and molar C:N ratios) were not consistent with the pattern of Se distribution in the clams, suggesting that they were not the predominant driver of the spatial distribution. This is contrary to conclusions from a recent modeling effort (Chen et al. 2012).

Temporal patterns of Se bioavailability were also clarified. Both seasonal and long-term patterns were similar station to station. This suggests that a set of processes common to all stations drove temporal variability within a level of contamination set by source inputs. A distinct, consistent seasonal cycle in Se concentrations in Potamocorbula amurensis appeared to be predominantly driven by seasonal differences in river inflows, with the highest concentrations occurring in the season with the lowest riverine inflows to the estuary and, thus, the least dilution of internal sources of Se. Combined hydrodynamic and Se bio-availability models predict a similar seasonality (Chen et al. 2012). Seasonal changes in food sources (and perhaps differences in Se bioavailability among these sources; Baines \& Fisher 2001) could not be eliminated as an additional driver of seasonality. But the nutritional quality of the food consumed by the clams was remarkably consistent, suggesting that changes in bioavailability through seasons would be driven by factors other than the quantities or proportion of chl $a$ and SPM. Unlike other metals, the size of the clam appeared to have only a minor influence on the seasonal cycle of Se and could be managed by standardizing to a common length (Cain \& Luoma 1990). Nor did it appear that variable Se loading from sources was the cause of the seasonality, since effluent monitoring shows that inputs from the refineries are relatively constant within a year, and any inputs from the San Joaquin River would be expected to be irregular because of the complexity of the water management system and delta transport (IEP 2006).

An interannual pattern in Se bioavailability was also evident. First, annual mean and mean fall Se concentrations declined an estimated 23 and $31 \%$, respectively, after refineries improved their waste treatment processes, eliminating selenite inputs and reducing total Se loadings to the estuary. Correcting for a small effect of clam size further highlighted the change driven by the improved waste treatment. Once the level of contamination was at a constant reduced magnitude, annual within-season differences in Se concentrations in the clams appeared to be driven by annual differences in freshwater inflows. Both $\delta^{15} \mathrm{~N}$ signatures in clams and chl a:SPM, indicators of food sources consumed, varied among years concurrent with freshwater inflows, suggesting that the source of the food rather than the quality of food consumed by the clams could not be eliminated as contributors to the long-term patterns of variability, again, linked to river inflows.

\section{Drivers of estuarine variability in Se bioavailability}

\section{Sources}

Detecting source inputs of Se is challenging in the physically and ecologically complex estuarine environment. In San Francisco Bay, Se inputs from local sources set the level of contamination within which temporal fluctuations in Se concentrations in Potamocorbula amurensis occur. Bioaccumulation models and observations from nature suggest that bivalves with biodynamics similar to $P$. amurensis bioaccumulate $\sim 1$ to $3 \mu \mathrm{g} \mathrm{g} \mathrm{g}^{-1}$ (dry wt, steady state) Se in undisturbed environments (e.g. Lee et al. 2006). Thus, Se in $P$. amurensis in San Francisco Bay appears to be enriched by 2 to $18 \mu^{-1} \mathrm{~g} \mathrm{~g}^{-1}$ of Se depending on where and when clams are sampled.

Proximity to Carquinez Strait had a significant impact on Se concentrations in the clams. Se concentrations were consistently $\sim 3$ to $4 \mu \mathrm{g} \mathrm{g}^{-1}$ higher in clams at Stn 8.1 in Carquinez Strait compared to stations located further up-estuary near the freshwater delta (Stns 4.1 and 415.1) or down-estuary at Stn 12.5 in San Pablo Bay. These spatial differences persisted over the $17 \mathrm{yr}$ time series, spanning a range of hydrologic and environmental conditions as well as changes in Se loading from local industries (Cutter \& Cutter 2004, Meseck \& Cutter 2006).

One explanation that has been proposed for the spatial distributions of Se in northern San Francisco Bay is the occurrence of hydrodynamic processes (i.e. gravitational circulation; Monismith et al. 2002) that either concentrate phytoplankton at Carquinez Strait (which is near Stn 8.1) or result in progressively increased residence time seaward and a progressive 
increase seaward in the standing stock of phytoplankton. Phytoplankton contain more bioavailable Se than other suspended particles (Schlekat et al. 2000). The landward to seaward $\delta^{13} \mathrm{C}$ pattern in Potamocorbula amurensis as well as chl a enrichment at Stn 12.5 relative to $\operatorname{Stn} 8.1$ were consistent with this hypothesis. But the spatial distribution of Se concentrations in the clam did not follow this pattern; Se concentrations in clams at Stn 12.5 were always less than those at Stn 8.1 (Table 3, Fig. S1A in Supplement A). Further, the enrichment of $\delta^{15} \mathrm{~N}$ in clams during years when X2 moved up-estuary indicated longer residence times and potentially greater local production within the bay. Indeed, the degree of $\delta^{15} \mathrm{~N}$ enrichment in clams could predict differences in $\mathrm{Se}$ concentrations at Stns 4.1 and 8.1 but only up to a point $\left(\delta^{15} \mathrm{~N} \approx 10 \%\right.$ ), beyond which Stn 8.1 always had higher Se than Stn 4.1. In both these cases, the distributions were those expected from dispersion of a constant source of input around Stn 8.1.

Modeling of potential dispersion from sources at Carquinez Strait took into consideration the complex interaction between Se loading, freshwater inflows and tides that occur. Results showed that internal sources of Se have the potential to be distributed throughout the northern estuary, particularly during low flow. These results do not consider factors such as residence times at different inflows or inputs from other sources, both of which also could influence Se bioavailability. Over the 17 yr period of study, Se concentrations in clams at Stn 8.1 were on average 33\% higher than concentrations at Stn 4.1 for the fall lowflow season, an amount that is slightly one-half that predicted by the model. Similarly, during high inflow, Potamocorbula amurensis retained a degree of Se enrichment not predicted by the model (Fig. 5, Table 3), even if all Se sources were eliminated. The discrepancies between the model and the observations raise the possibility of additional sources of enriched Se that is bioavailable in the northern estuary. The most likely sources would be occasional inputs from the San Joaquin River.

The San Joaquin River historically provided 20\% of the estuarine inflow. It now receives agriculture irrigation drainage elevated in Se and has total dis-

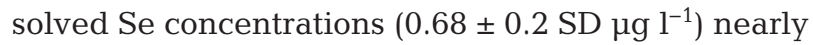
10 to 50 times that of the Sacramento River (Cutter \& Cutter 2004). However, the influence on the bay of the Se-enriched inflows from the San Joaquin River remains unclear because (1) direct inflows from the San Joaquin River to the bay are mostly limited to high-flow months, since net flows during the summer and fall are almost always negative because of water diversions (IEP 2006); and (2) the delta that lies between the San Joaquin River and the bay is probably a sink for Se removal, but the magnitude of that removal remains uncertain (Meseck \& Cutter 2006). These factors suggest that if inputs from the San Joaquin River have a detectable influence on Se bioavailability in the bay, it would be temporally complex and unlikely to explain the seasonal patterns of fluctuation in Se concentrations. As noted above regarding the model results, aspects of the longer-term patterns of change in fall and spring Se concentrations could be influenced by aperiodic inputs from the San Joaquin River, superimposed on the dominant effects of inflows in diluting Se bioavailability in high-flow years and allowing greater overall bioaccumulation in low-flow years. If inflows of San Joaquin River to the bay were to increase (e.g. under some of the water management scenarios being proposed for the future), it seems feasible that this source of contamination could become more important.

\section{Riverine inflows}

Seasonal freshwater inflow from the delta explained 68 and $46 \%$ of the month-to-month variation in Se concentrations in clams at Stns 4.1 and 8.1, respectively. The Sacramento River provides the largest proportion of freshwater flow to San Francisco Bay and has a low and constant total dissolved Se concentration of $0.072 \pm 0.021 \mu \mathrm{g} \mathrm{l}^{-1}$ (Cutter \& Cutter 2004). During the summer and fall low-flow periods, the Sacramento River may supply as much as $\sim 1000 \mathrm{~g} \mathrm{~d}^{-1}$ of Se to the estuary. During high inflows, a larger load of Se will enter the estuary from the river but in a proportionately larger volume of water. Because the mass of Se per unit volume of water does not change with inflows (concentrations are relatively constant at $0.07 \mathrm{\mu g} \mathrm{l}^{-1}$; Cutter \& Cutter 2004), the larger load will not change the concentration in the estuary. If sources internal to the estuary are present (e.g. industrial inputs), larger riverine inflows will dilute those concentrations proportional to the inflows, as the load from the internal sources becomes a small proportion of the riverine load (e.g. Cutter \& San Diego-McGlone 1990). Dilution would be the simplest explanation for the seasonal fluctuation in Se concentrations in Potamocorbula amurensis, as well as the riverine-driven portion of the interannual variability. Because the biomonitor concentrates Se and integrates changing bioavailable Se over time, the temporal signals in $P$. amurensis were more distinct 
than spatiotemporal signals in earlier studies of either dissolved Se or Se associated with particulates (on a mass particulate basis; Cutter \& Cutter 2004, Doblin et al. 2006).

Processes other than just dilution could affect inflow-linked seasonal or interannual fluctuations in Potamocorbula amurensis. Although tidal currents in the estuary are strong, most models suggest that longer residence times are likely as inflows recede in the summer and fall. Longer residence times would allow greater transformation of dissolved Se to particulate Se (via phytoplankton uptake) without, necessarily, large changes in Se concentrations in the total particulate mass (Baines et al. 2004, Doblin et al. 2006, G. A. Cutter pers. comm.). This could create a larger pool of bioavailable Se during the fall season, in particular. This effect could superimpose temporal variability upon the spatial pattern, but the lack of spatial correlation with existing indicators of nutritional sources and quality show that it did not drive the spatial pattern. Further, the fact that monthly chl a concentrations were significantly correlated to monthly clam Se concentrations without incorporating a lag suggests that phytoplankton biomass did not have an effect on seasonal clam Se but, rather, that variations in both chl $a$ and Se concentrations were coincident with changes in freshwater inflow.

Linked 3D hydrodynamic and phytoplankton models that include source inputs of Se in the northern estuary may provide further understanding.

\section{Influence of clam size and nutrition on Se concentrations}

It is well recognized that biological processes like growth and reproductive status can influence mean concentrations of Se in estuarine bivalves (reviewed by Luoma \& Rainbow 2008), but rarely are such effects quantified compared to other influences on bioaccumulation. In the case of Potamocorbula amurensis, that influence was relatively subtle and did not change the results. Adjusting Se concentrations in the clams to a common length removed the effect of allometric variation (Wang \& Dei 1999a, Lee et al. 2006) on mean Se concentrations and allowed a more accurate determination of the magnitude of the refinery effect.

Despite the apparent variation in the source of food (imported or locally grown) consumed by the clams in the present study, the nutritional quality of the food appeared consistent in time and space and was probably not a key driver in determining Se concen- trations in clams. As Se is incorporated into cells as selenoamino acids (i.e. selenocysteine; Hatfield et al. 1999) and selenoproteins (Vanda Papp et al. 2007), strong variation in the relative elemental composition of soft tissues during spawning (Smaal \& Vonck 1997) or as a result of nutrient stress (Okumura et al. 2002) could indicate effects on the nitrogen pool that binds Se within the organism relative to body weight. But this physiological condition was not indicated by the consistent C:N ratios of Potamocorbula amurensis across the samples (spatial, seasonal or interannual) in the time series.

\section{CONCLUSIONS}

Long-term biomonitoring of bioaccumulated contaminants can provide unique insights into the processes that control exposure of the food web to Se. Accumulation of Se in consumer organisms such as bivalves like Potamocorbula amurensis determines the degree of contamination and species in the upper trophic levels that will be most at risk from reproductive toxicity of the element (Stewart et al. 2004, 2010, Presser \& Luoma 2010). In the present paper, the 17 yr, near-monthly data set for the biomonitor $P$. amurensis, when combined with relevant ancillary chemical and isotope data and a preliminary physical model, provides the clearest indication to date of how Se inputs, biological and ecological processes and riverine inflows interact to produce spatially, seasonally and annually fluctuating contamination at the base of the San Francisco Bay estuarine food web.

A combination of biomonitoring, isotope determinations and historical chemical data (Cutter \& Cutter 2004, Doblin et al. 2006) indicate that spatial distributions of contamination are best explained by a source of contamination near Carquinez Strait, most likely refineries from which Se inputs are well documented (Cutter 1989, Cutter \& Cutter 2004). Riverine inflows provide a powerful modulating force on the sourcedriven level of Se contamination, driving bioavailable concentrations up and down as inflows change seasonally and year to year. Inflows exert their effects via dilution, residence time and nutritional inputs. Assessment of risks to estuaries from contaminants, and their subsequent regulation, is too often limited to evaluation of source inputs and their chemistry in the environment. Environmental influences like riverine inflows are one necessary consideration if overall implications of the contamination are to be understood. The present study shows that bioavailability of contaminants to crucial species in the food 
web can be monitored effectively. Evaluation of biomonitoring data over the long term with adequate spatial coverage can provide information on processes influencing the fate and effects of contaminants that are otherwise unavailable.

Acknowledgements. We thank J. Thompson for her helpful comments on the manuscript, the crew of the RV 'Polaris' for their assistance with sample collection and the University of California at Davis Stable Isotope Facility. Support for this long-term study was provided by USGS-appropriated funds, including the Hydrologic Research and Development, Priority Ecosystem Science, and Toxic Substances Hydrology programs, as well as grants from the California Delta Science Program (formerly CALFED). This work was also conducted as part of 'CASCaDE: Computational Assessments of Scenarios of Change for the Delta Ecosystem' supported by the California Delta Science Program. Any opinions, findings and conclusions or recommendations expressed in this material are those of the authors and do not necessarily reflect the views of the Delta Science Program. This is CASCaDE publication no. 18.

\section{LITERATURE CITED}

Ackerman JT, Eagles-Smith CA (2009) Selenium bioaccumulation and body condition in shorebirds and terns breeding in San Francisco Bay, California, USA. Environ Toxicol Chem 28:2134-2141

Baines SB, Fisher NS (2001) Interspecific differences in the bioconcentration of selenite by phytoplankton and their ecological implications. Mar Ecol Prog Ser 213:1-12

> Baines SB, Fisher NS, Doblin MA, Cutter GA, Cutter LS, Cole B (2004) Light dependence of selenium uptake by phytoplankton and implications for predicting selenium incorporation into food webs. Limnol Oceanogr 49:566-578

Brown CL, Luoma SN (1995) Use of the euryhaline bivalve Potamocorbula amurensis as a biosentinel species to assess trace metal contamination in San Francisco Bay. Mar Ecol Prog Ser 124:129-142

Cabana G, Rasmussen JB (1996) Comparison of aquatic food chains using nitrogen isotopes. Proc Natl Acad Sci USA 93:10844-10847

Cain DJ, Luoma SN (1986) Effect of seasonally changing tissue weight on trace metal concentrations in the bivalve Macoma balthica in San Francisco Bay. Mar Ecol Prog Ser 28:209-217

> Cain DJ, Luoma SN (1990) Influence of seasonal growth, age, and environmental exposure on $\mathrm{Cu}$ and $\mathrm{Ag}$ in a bivalve indicator, Macoma balthica, in San Francisco Bay. Mar Ecol Prog Ser 60:45-55

> Canuel EA, Cloern JE, Rinelberg DB, Gucket JB (1995) Molecular and isotopic tracers used to examine sources of organic matter and its incorporation into the food webs of San Francisco Bay. Limnol Oceanogr 40:67-81

Chapman PM, Adams WJ, Brooks M, Delos CG and others (eds) (2010) Ecological assessment of selenium in the aquatic environment. SETAC Press, Pensacola, FL

Chen L, Meseck SL, Roy SB, Grieb TM, Baginska B (2012) Modeling fate, transport, and biological uptake of selenium in north San Francisco Bay. Estuaries Coast 35: $1551-1570$
Cloern JE, Canuel EA, Harris D (2002) Stable carbon and nitrogen isotope composition of aquatic and terrestrial plants of the San Francisco Bay estuarine system. Limnol Oceanogr 47:713-729

> Cutter GA (1989) The estuarine behavior of selenium in San Francisco Bay. Estuar Coast Shelf Sci 28:13-34

> Cutter GA, Cutter LS (2004) Selenium biogeochemistry in the San Francisco Bay estuary: changes in water column behavior. Estuar Coast Shelf Sci 61:463-476

Cutter GA, San Diego-McGlone MLC (1990) Temporal variability of selenium fluxes in San Francisco Bay. Sci Total Environ 97-98:235-250

> Doblin MA, Baines SB, Cutter LS, Cutter GA (2006) Sources and biogeochemical cycling of particulate selenium in the San Francisco Bay estuary. Estuar Coast Shelf Sci 67: 681-694

Elrick KA, Horowitz AJ (1985) Analysis of rocks and sediments for arsenic, antimony, and selenium, by wet digestion and hydride atomic absorption. US Geological Survey Open-File Report 85-497

- Elser JJ, Fang FW, Denno FR, Dobberfuhl RD and others (2000) Nutritional constraints in terrestrial and freshwater food webs. Nature 408:578-580

France RL (1995) Differentiation between littoral and pelagic food webs in lakes using stable carbon isotopes. Limnol Oceanogr 40:1310-1313

> Ganju N, Schoellhamer D (2006) Annual sediment flux estimates in a tidal strait using surrogate measurements. Estuar Coast Shelf Sci 69:165-178

Gross ES, MacWilliams ML, Kimmerer WJ (2010) Threedimensional modeling of tidal hydrodynamics in the San Francisco Estuary. San Francisco Estuary Watershed Sci 7. Available at http://escholarship.org/uc/item/9rv243mg

Hatfield DL, Gladyshev VN, Park SI, Chittum HS, Carlson BA, Moustafa ME (1999) Biosynthesis of selenocystein and its incorporation into proteins as the 21st amino acid. Comp Nat Prod Chem 4:353-380

IEP (Interagency Ecological Program) (2006) Dayflow. California Department of Water Resources. Available at www.water.ca.gov/dayflow/

Jassby A (2008) Phytoplankton in the upper San Francisco Estuary: recent biomass trends, their causes and their trophic significance. San Francisco Estuary Watershed Sci 6. Available at http://escholarship.org/uc/item/71h 077r1

Jassby AD, Kimmerer WJ, Monismith SG, Armor C and others (1995) Isohaline position as a habitat indicator for estuarine populations. Ecol Appl 5:272-289

Johns C, Luoma SN, Elrod V (1988) Selenium accumulation in benthic bivalves and fine sediments of San Francisco Bay, the Sacramento-San Joaquin Delta, and selected tributaries. Estuar Coast Shelf Sci 27:381-396

Kimmerer WJ (2002) Effects of freshwater flow on abundance of estuarine organisms: physical effects or trophic linkages. Mar Ecol Prog Ser 243:39-55

Kleckner AE, Stewart AR, Elrick KA, Luoma SN (2010) Selenium concentrations and stable isotopic compositions of carbon and nitrogen in the benthic clam Corbula amurensis from northern San Francisco Bay, California: May 1995-February 2010. US Geological Survey OpenFile Report 2010-1252

Lee BG, Lee JS, Luoma SN (2006) Comparison of selenium bioaccumulation in the clams Corbicula fluminea and Potamocorbula amurensis: a bioenergetic modeling approach. Environ Toxicol Chem 25:1933-1940 
Linville RG, Luoma SN, Cutter L, Cutter GA (2002) Increased selenium threat as a result of invasion of the exotic bivalve Potamocorbula amurensis into the San Francisco Bay-Delta. Aquat Toxicol 57:51-64

Luoma SN, Rainbow PS (2008) Metal contamination in aquatic environments. Cambridge University Press, Cambridge

Luoma SN, Johns C, Fisher NS, Steinberg NA, Oremland RS, Reinfelder JR (1992) Determination of selenium bioavailability to a benthic bivalve from particulate and solute pathways. Environ Sci Technol 26:485-491

Meseck SL, Cutter GA (2006) Evaluating the biogeochemistry of selenium in San Francisco Bay through modeling. Limnol Oceanogr 51:2018-2032

Monismith SG, Kimmerer W, Burau JR, Stacey MT (2002) Structure and flow-induced variability of the subtidal salinity field in northern San Francisco Bay. J Phys Oceanogr 32:3003-3019

Nichols FH, Cloern JE, Luoma SN, Peterson DH (1986) The modification of an estuary. Science 231:567-573

Ohlendorf HM, Lowe RW, Harvey TE, Kelly PR (1989) Selenium and heavy metals in San Francisco Bay diving ducks. J Wildl Manag 50:64-71

Ohlendorf HM, Marois KC, Lowe RW, Harvey TE, Kelly PR (1991) Trace elements and organochlorines in surf scoters from San Francisco Bay, 1985. Environ Monit Assess 18:105-122

Okumura T, Nagasawa T, Hayashi I, Sato Y (2002) Effects of starvation on RNA:DNA ratio, glycogen content, and $\mathrm{C}: \mathrm{N}$ ratio in columellar muscle of the Japanese turban shell Turbo (Batillus) cornutus (Gastropoda). Fish Sci 68: 306-312

> Peterson BJ, Fry B (1987) Stable isotopes in ecosystem studies. Annu Rev Ecol Syst 18:293-320

Poulton VK, Lovvorn JR, Takekawa JY (2004) Spatial and overwinter changes in clam populations of San Pablo Bay, a semiarid estuary with highly variable freshwater inflow. Estuar Coast Shelf Sci 59:459-473

Presser TS, Luoma SN (2010) A methodology for ecosystemscale modeling of selenium. Integr Environ Assess Manag 6:685-710

Presser TS, Ohlendorf HM (1987) Biogeochemical cycling of selenium in the San Joaquin Valley, California, USA. Environ Manag 11:805-821

SAS Institute (2010) Using JMP 9. SAS Institute, Cary, $\mathrm{NC}$

Editorial responsibility: Inna Sokolova,

Charlotte, North Carolina, USA
Schlekat CE, Dowdle PR, Lee BG, Luoma SN, Oremland RS (2000) Bioavailability of particle-associated Se to the bivalve Potamocorbula amurensis. Environ Sci Technol 34:4504-4510

Schlekat CE, Lee BG, Luoma SN (2002) Assimilation of selenium from phytoplankton by three benthic invertebrates: effect of phytoplankton species. Mar Ecol Prog Ser 237: 79-85

Smaal AC, Vonck APMA (1997) Seasonal variation in C, N and $\mathrm{P}$ budgets and tissue composition of the mussel Mytilus edulis. Mar Ecol Prog Ser 153:167-179

Spiker EC, Schemel LE (1979) Distribution and stableisotope composition of carbon in San Francisco Bay. In: Conomos TJ (ed) San Francisco Bay: the urbanized estuary. American Association for the Advancement of Science, San Francisco, CA, p 195-212

Stewart AR, Luoma SN, Schlekat CE, Doblin MA, Hieb KA (2004) Food web pathway determines how selenium affects aquatic ecosystems: a San Francisco Bay case study. Environ Sci Technol 38:4519-4526

Stewart AR, Grosell M, Buchwalter DB, Fisher N and others (2010) Bioaccumulation and trophic transfer of selenium. In: Chapman PM, Adams WJ, Brooks ML, Delos CG and others (eds) Ecological assessment of selenium in the aquatic environment. SETAC Press, Pensacola, FL, p 93-139

Taylor K, Pease W, Lacy J, Carlin M (1992) Mass emissions reduction strategy for selenium. Technical Report, San Francisco Bay Regional Water Quality Control Board, California Environmental Protection Agency, Oakland, CA

> van der Wegen M, Jaffe BE, Roelvink JA (2011) Processbased, morphodynamic hindcast of decadal deposition patterns in San Pablo Bay, California, 1856-1887. J Geophys Res 116:F02008, doi:10.1029/2009JF001614

Vanda Papp L, Lu J, Holmgren A, Khanna KK (2007) From selenium to selenoproteins: synthesis, identity, and their role in human health. Antioxid Redox Signal 9:775-806

Wang WX, Dei RCH (1999a) Factors affecting trace element uptake in the black mussel Septifer virgatus. Mar Ecol Prog Ser 186:161-172

Wang WX, Dei RCH (1999b) Kinetic measurements of metal accumulation in two marine macroalgae. Mar Biol 135: 11-23

Wilber CG (1980) Toxicology of selenium: a review. Clin Toxicol 17:171-230

Submitted: January 2, 2013; Accepted: August 5, 2013

Proofs received from author(s): October 23, 2013 